
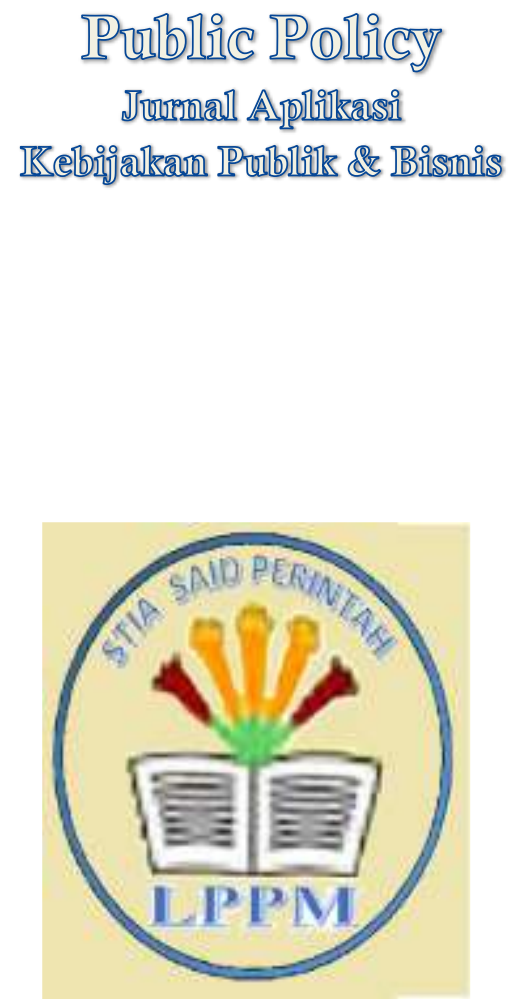

LPPM STIA Said Perintah

Volume 1, No. 2, September 2020

https://stia-saidperintah.e-journal.id/ppi

\section{Dampak Lingkungan Kerja dan Etos Kerja Terhadap Kinerja Pegawai}

\author{
Herman Philips Dolonseda ${ }^{1}$ \\ Sjeddie R. Watung ${ }^{2}$ \\ 1,2 Universitas Negeri Manado \\ sjeddiewatung@unima.ac.id
}

\begin{abstract}
This study aims to determine the effect of work environment and work ethic on employee performance in the Regional Education and Culture Office of Sangihe Islands Regency. This study used a survey research method, where the research instrument was a tested questionnaire and met the validity and reliability test requirements. Data were analyzed using multiple regression analysis. The population in this study were all employees at the Education and Culture Office of the Sangihe Islands Regency totaling 70 people, while the number of samples was 60 people. The results show that there is an influence of the work environment on the performance of employees at the Regional Education and Culture Office of the Sangihe Islands Regency, there is an influence of work ethic on the performance of employees at the Regional Education and Culture Office of the Sangihe Islands Regency, and there is a joint influence on the work environment and work ethic on the performance of employees at the Regional Education and Culture Office of Sangihe Islands Regency.

Keywords : Work Environment, Work Ethic, Employee Performance
\end{abstract}

\title{
Pendahuluan
}

Sebuah kantor dalam menjalankan kegiatan roda pemerintahan memiliki beberapa faktor yang saling terikat dan berpengaruh. Salah satu faktor yang sangat penting yang digunakan untuk menjalankan roda pemerintahan yaitu sumber daya manusia. Maka dari itu kantor dalam menjalankan roda pemerintahan dituntut untuk mengelola dan mengoptimalkan sumber daya manusia. Menurut Wirawan, (2009) sumber daya manusia penting karena berperan untuk menggerakan dan menyinergikan sumber daya lainnya untuk mencapai tujuan organisasi. Organisasi dapat berjalan efektif apabila sumber daya manusianya berjalan efektif. Menurut Sondang P. Siagian, (2010) kinerja karyawan dipengaruhi oleh beberapa faktor yaitu; gaji, lingkungan kerja, budaya organisasi, 
kepemimpinan dan motivasi kerja, disiplin kerja, kepuasan kerja, komunikasi dan faktorfaktor lainnya.

Berdasarkan beberapa faktor di atas, untuk meningkatkan kinerja karyawan salah satunya adalah dengan memperhatikan faktor lingkungan kerja. Organisasi kantor merupakan tempat pegawai bekerja harus menghadirkan lingkungan kerja yang nyaman untuk bekerja, sehingga kinerja pegawai dapat terus meningkat. Winardi, (2007) mengungkapkan lingkungan kerja merupakan suatu alat ukur yang akan berpengaruh terhadap kinerja pegawai jika lingkungan kerja yang ada pada instansi itu baik. Lingkungan kerja yang menyenangkan bagi pegawai melalui peningkatan hubungan yang harmonis dengan atasan, rekan kerja, maupun bawahan, serta didukung oleh sarana dan prasarana yang memadai yang ada di tempat kerja akan membawa dampak yang positif bagi pegawai, sehingga kinerja pegawai dapat meningkat. Kondisi lingkungan kerja yang kurang baik dapat menyebabkan para karyawan mudah stres, tidak ada semangat untuk bekerja, datang tidak tepat waktu, begitu pula sebaliknya apabila lingkungan kerja itu baik maka para karyawan tentunya akan memiliki semangat dalam bekerja, tidak mudah sakit, bahkan mudah untuk konsentrasi dalam melaksanakan pekerjaan.

Selain Lingkungan Kerja, Etos Kerja juga menjadi hal penting dalam meningkatkan kinerja pegawai. Hasil penelitian Saleha, (2016) membuktikan bahwa kinerja pegawai pada suatu instansi dapat ditingkatkan dengan memperhatikan etos kerja pegawai. Menurut Sinamo Jansen, (2011) etos merupakan kunci dan fondasi keberhasilan suatu masyarakat atau bangsa diterima secara aklamasi. Selain itu etos merupakan syarat utama bagi semua upaya peningkatan kualitas tenaga kerja atau SDM dalam hal ini kinerja, baik pada level individual, organisasional, maupun sosial.

Menurut Salamun, (1995) seorang pegawai yang memiliki etos kerja yang tinggi diindikasikan dengan: (1) kerja keras, dimana pegawai mempunyai sifat mabuk kerja untuk dapat mencapai sasaran yang ingin dicapai, (2) disiplin kerja, dimana pegawai memiliki sikap menghormati menghargai patuh dan taat terhadap peraturan-peraturan yang berlaku, (3) jujur, dimana pegawai dalam menjalankan pekerjaannya sesuai dengan aturan yang sudah ditentukan, (4) tanggung jawab, dimana pekerjaan yang dilakukan merupakan sesuatu yang harus dikerjakan dengan ketekunan dan kesungguhan, (5) rajin, terciptanya kebiasaan pribadi karyawan untuk menjaga dan meningkatkan apa yang 
sudah dicapai, dan (6) tekun berarti rajin, keras hati, dan bersungguh-sungguh (bekerja, belajar, berusaha).

\section{Kerangka Teoritis dan Pengembangan Hipotesis Lingkungan Kerja}

Lingkungan kerja Menurut Alex Nitisemito, (2011) adalah segala sesuatu yang ada disekitar pekerja dan dapat mempengaruhi mereka dalam menjalankan tugas-tugas yang dibebankan. Untuk menciptakan lingkungan kerja yang baik ada beberapa hal yang harus diperhatikan yaitu (Sondang P. Siagian, 2010) bahwa 1). Bangunan tempat kerja, 2). Ruang kerja yang lega, 3). Ventilasi pertukaran udara, 4). Tersedianya tempat-tempat ibadah keagamaan, 5). Tersedianya sarana angkutan khusus maupun umum untuk karyawan nyaman dan mudah.

Lingkunga kerja fisik maupun psikis keduanya sama pentingnya dalam sebuah organisasi, kedua lingkungan kerja ini tidak bisa dipisahkan. Apabila sebuah organisasi hanya mengutamakan satu jenis lingkungan kerja saja, tidak akan tercipta lingkungan kerja yang baik, dan lingkungan kerja yang kurang baik dapat menuntut tenaga kerja dan waktu yang lebih banyak dan tidak mendukung diperolehnya rancangan sistem kerja yang efisien dan akan menyebabkan organisasi tersebut mengalami penurunan produktivitas kerja.

Manfaat lingkungan kerja adalah menciptakan gairah kerja, sehingga produktivitas kerja meningkat. Sementara itu, manfaat yang diperoleh karena bekerja dengan orangorang yang termotivasi adalah pekerjaan dapat diselesaikan dengan tepat. Artinya pekerjaan diselesaikan sesuai standar yang benar dan dalam skala waktu yang ditentukan. Kinerjanya akan dipantau oleh individu yang bersangkutan dan tidak akan membutuhkan terlalu banyak pengawasan serta semangat juangnya akan tinggi (Arep, Ishak dan Hendri, 2003).

Berdasarkan uraian di atas, maka penulis merumuskan hipotesis penelitian sebagai berikut;

$\mathrm{H}_{1} \quad$; Terdapat pengaruh lingkungan kerja terhadap kinerja pegawai di Dinas Pendidikan dan Kebudayaan Daerah Kabupaten Kepulauan Sangihe.

\section{Etos Kerja}

Tasmara, (2002) mengatakan bahwa etos kerja adalah suatu totalitas kepribadian dari pegawai serta cara pegawai mengekspresikan, mamandang, meyakini dan memberikan 
makna terhadap sesuatu yang mendorong pegawai untuk bertindak dan meraih hasil yang optimal. Tasmara, (2002) mengajukan empat bentuk dimensi etos kerja, demensi tersebut terdiri atas;

a. Disiplin, adalah kondisi yang merupakan perwujudan sikap mental dan perilaku seorang pegawai ditinjau dari aspek kepatuhan dan ketaatan terhadap ketentuan peraturan dan hukum yang berlaku pada organisasi.

b. Kerja sama, adalah sikap kesediaan untuk melakukan kegiatan atau usaha dengan atasan, sesama pegawai dan bawahan untuk mencapai tujuan bersama.

c. Adil, adalah sikap tidak berat sebelah, tidak memihak, berpihak kepada yang benar, berpegang kepada kebenaran sehingga sebagai pemimpin tidak bertindak sewenangwenang.

d. Peduli, adalah sikap mengindahkan, memperhatikan dan menghiraukan pegawai lain dalam organisasi. Peduli juga berarti sikap atas kesediaan untuk memperhatikan lingkungan dimana kita berada yang dilandasi oleh keyakinan bahwa baik-buruknya lingkungan tersebut merupakan bagian dari andil pegawai.

Berdasarkan uraian di atas, maka penulis merumuskan hipotesis penelitian sebagai berikut:

$\mathrm{H}_{2} \quad$; Terdapat pengaruh etos kerja terhadap kinerja pegawai di Dinas Pendidikan dan Kebudayaan Daerah Kabupaten Kepulauan Sangihe.

\section{Kinerja Pegawai}

Mangkunegara, (2000) mengatakan bahwa kinerja pegawai adalah hasil kerja secara kualitas dan kuantitas yang dicapai oleh seseorang pegawai dalam melaksanakan tugasnya sesuai dengan tanggungjawab yang diberikan kepadanya. Pada akhirnya, A.A Anwar Prabu Mangkunegara, (2005) menyimpulkan bahwa faktor- faktor penentu prestasi kerja individu dalam organisasi adalah: Faktor individu dan Faktor lingkungan kerja organisasi. Pembagian faktor-faktor ini sejalan dengan Timpe, (1992) dalam A.A Anwar Prabu Mangkunegara, (2005) menyatakan bahwa faktor-faktor kinerja terdiri dari faktor internal dan faktor eksternal. Faktor internal yaitu factor yang dihubungkan dengan sifat-sifat seseorang. Adapun faktor eksternal, yaitu faktor- faktor yang mempengaruhi kinerja seseorang yang berasal dari lingkungan. Faktor internal dan faktor eksternal ini merupakan jenis-jenis atribusi yang mempengaruhi kinerja seseorang. Jenis-jenis atribusi yang dibuat para 
karyawan memiliki sejumlah akibat psikologis dan berdasarkan kepada tindakan. Dengan kata lain, faktor individu dapat dikategorikan sebagai faktor internal dan faktor lingkungan kerja organisasi sebagai faktor eksternal. Mengukur kinerja pegawai/ karyawan dimaksudkan untuk menilai tingkat kinerja pegawai dalam periode waktu tertentu. Menurut Malayu S.P. Hasibuan dalam A.A Anwar Prabu Mangkunegara, (2005) mengemukakan bahwa aspek-aspek yang dinilai kinerja mencakup sebagai berikut: kesetiaan, hasil kerja, kejujuran, kedisiplinan, kreativitas, kerjasama, kepemimpinan, kepribadian.

Berdasarkan uraian di atas, maka penulis merumuskan hipotesis penelitian sebagai berikut:

$\mathrm{H}_{3} \quad$; Terdapat pengaruh lingkungan kerja dan etos kerja secara bersama-sama terhadap kinerja pegawai di Dinas Pendidikan dan Kebudayaan Daerah Kabupaten Kepulauan Sangihe.

\section{Metode Penelitian}

Penelitian ini menggunakan metode penelitian survei dimana peneliti menggunakan alat bantu kuesioner untuk melakukan penelitian. Populasi dalam penelitian ini adalah seluruh pegawai yang ada di Dinas Pendidikan Kabupaten Kepulauan Sangihe berjumlah 70 pegawai. Untuk menentukan besar ukuran sampel, peneliti menggunakan formula Slovin dengan tingkat kesalahan yang ditetapkan sebesar 0,05 atau 5\%, dari jumlah populasi 70 pegawai, maka diperoleh ukuran sampel 60 . Instrumen yang digunakan dalam penelitian ini meliputi 3 variabel penelitian yaitu: (1) variabel lingkungan kerja; (2) variabel etos kerja; (3) variabel kinerja pegawai. Instrumen penelitian yang digunakan untuk masing-masing variabel menggunakan skala Likert. Instrumen tersebut diuji cobakan kepada 30 pegawai sebagai responden yang diambil secara acak. Responden uji coba adalah mereka yang tidak termasuk sebagai responden penelitian. Proses kalibrasi dilakukan dengan menganaslisis data hasil uji coba instrumen untuk menguji validitas instrumen dalam hal ini validitas butir dengan menggunakan koefisien korelasi antar skor butir dengan skor total instrumen. Rumus yang digunakan adalah rumus Korelasi Product Moment.

Definisi operasional variabel (1) Variabel Kinerja Pegawai (Y) adalah perilaku nyata yang ditampilkan setiap orang sebagai prestasi kerja yang dihasilkan oleh pegawai sesuai dengan perannya. Dengan indikator: kualitas, kuantitas, ketepatan waktu, efektivitas dan 
komitmen kerja. (2) Variabel lingkungan Kerja $\left(\mathrm{X}_{1}\right)$ adalah suatu kondisi dimana para pegawai bekerja dalam suatu kantor yang dapat mempengaruhi kondisi fisik dan psikologi pegawai baik secara langsung maupun tidak langsung sehingga lingkungan kerja dapat dikatakan baik apabila pegawai dapat bekerja dengan optimal, tenang dan produktivitasnya tinggi. Indikator pengukurnya antara lain; pewarnaan ruangan, kebersihan, pertukaran udara, penerangan, keamanan, dan kebisingan. (3) Variabel etos kerja $\left(\mathrm{X}_{2}\right)$ adalah totalitas kepribadian dirinya serta caranya mengekspresikan, memandang, meyakini dan memberikan makna ada sesuatu, yang mendorong dirinya untuk bertindak dan meraih amal yang optimal sehingga pola hubungan antara manusia dengan dirinya dan antara manusia dengan makhluk lainnya dapat terjalin dengan baik dengan indikator: kesadaran, semangat, kemauan, disiplin kerja, inisiatif, dan produktif.

Data yang dikumpulkan dalam penelitian ini adalah data subyek saja. Data subyek berupa persepsi atau pendapat dari responden secara tertulis atas kuesioner yang diberikan. Pengumpulan data dilakukan melalui penyebaran kuesioner (angket) kepada responden lewat google forms yang sudah ditetapkan menjadi sampel penelitian ini, yaitu variabel $\mathrm{X}_{1}$ (lingkungan kerja) dan $\mathrm{X}_{2}$ (etos kerja), dan $Y$ (kinerja pegawai). Teknik analisis data yang akan digunakan tidak lepas dari paradigma penelitian yakni regresi linier berganda.

\section{Pembahasan Hasil Penelitian}

\section{Analisis Data Penelitian}

Salah satu persyaratan dalam penggunaan statistik, uji yang tergolong parametrik adalah uji normalitas. Uji ini dilakukan untuk memastikan apakah data yang dikumpulkan dari responden berasal dari populasi yang berdistribusi normal atau tidak. Satu uji yang sering digunakan untuk menguji normalitas data adalah uji liliefors. Salah satu kelebihan dari uji normalitas ini adalah penggunaan daftar distribusi z untuk perhitungan kenormalan data. Hipotesis yang menjadi petunjuk untuk uji ini adalah

$\mathrm{H}_{0}=\mathrm{L}_{\text {Hitung }}<\mathrm{L}_{\text {Tabel }}=$ data berasal dari populasi berdistribusi normal

$\mathrm{H}_{\mathrm{a}}=\mathrm{L}_{\text {Hitung }}>\mathrm{L}_{\text {Tabel }}=$ data berasal dari populasi tidak berdistribusi normal

Berdasarkan data hasil penelitian dapat dan dijelaskan keadaan data hasil pengujian normalitas untuk masing-masing variabel penelitian pada tabel berikut; 


\begin{tabular}{|c|c|c|c|}
\hline Variabel & $\mathrm{L}_{\text {Tabel }} \mathrm{a}=0,05$ & $\mathrm{~L}_{\text {Hitung }}$ & Keterangan \\
\hline Lingkungan Kerja $(\mathrm{X} 1)$ & 0,11 & 0,06 & Normal \\
\hline Etos Kerja $(\mathrm{X} 2)$ & 0,11 & 0,04 & Normal \\
\hline Kinerja Pegawai $(\mathrm{Y})$ & 0,11 & 0,05 & Normal \\
\hline
\end{tabular}

Berdasarkan data pada tabel 1 ternyata data variabel $\mathrm{X}_{1}, \mathrm{X}_{2}$, dan $\mathrm{Y}$ berdistribusi normal sehingga dapat dilanjutkan untuk pengujian hipotesis.

\section{Pengujian Hipotesis}

1. Dampak lingkungan kerja $\left(\mathrm{X}_{1}\right)$ terhadap kinerja pegawai $(\mathrm{Y})$

Ada pengaruh yang positif dan signifikan lingkungan kerja terhadap kinerja pegawai. Hal ini ditunjukan dengan nilai $t$ hitung $=8,07$, sedangkan $t$ tabel $=2,00$, maka dengan demikian hipotesis yang mengatakan terdapat pengaruh lingkungan kerja terhadap kinerja pegawai diterima.

2. Pengaruh etos kerja $\left(\mathrm{X}_{2}\right)$ terhadap kinerja pegawai $(\mathrm{Y})$

Ada pengaruh yang positif dan signifikan etos kerja terhadap kinerja pegawai. Hal ini ditunjukan dengan nilai $\mathrm{t}$ hitung $=9,03$, sedangkan $\mathrm{t}$ tabel $=2,00$, maka dengan demikian hipotesis yang mengatakan terdapat pengaruh etos kerja terhadap kinerja pegawai dapat diterima.

3. Pengaruh lingkungan kerja $\left(X_{1}\right)$ dan etos kerja $\left(X_{2}\right)$ terhadap kinerja pegawai $(Y)$ Ada pengaruh yang positif dan signifikan lingkungan kerja dan etos kerja secara bersama sama terhadap kinerja pegawai. Hal ini ditunjukan dengan nilai signifikansi $F$, dimana nilai $\mathrm{F}$ hitung $=55,21>\mathrm{F}$ tabel $=4,00$.

\section{Pembahasan}

\section{Dampak Lingkungan Kerja Terhadap Kinerja Pegawai}

Berdasarkan hasil analisis data, hipotesis penelitian yang menyatakan bahwa lingkungan kerja berpengaruh terhadap kinerja pegawai di Dinas Pendidikan dan Kebudayaan Daerah Kabupaten Kepulauan Sangihe diterima. Pengaruh ini berdasarkan nilai $\mathrm{t}$ hitung $=8,07$ sedangkan $\mathrm{t}$ tabel $=2,00$. Hasil analisis data ini menjelaskan bahwa lingkungan kerja memberikan kontribusi yang berarti terhadap kinerja pegawai. 
Lingkungan kerja yang baik dihadirkan oleh instansi akan sangat bermanfaat bagi perjalanan hidup dari instansi dikarenakan tidak sedikit instansi gulung tikar disebabkan karna lingkungan kerja yang tidak baik. Lingkungan kerja yang baik yang dihadirkan oleh pegawai dan instansi akan mendorong efektivitas dari instansi tersebut didalam menjalankan roda pemerintahan. Bahkan akan memunculkan semangat dan gairah kerja yang tinggi karena adanya lingkungan kerja yang baik dan menyenangkan. Diungkapkan oleh Winardi, (2007) lingkungan kerja merupakan suatu alat ukur yang akan berpengaruh terhadap kinerja pegawai jika lingkungan kerja yang ada pada instansi itu baik. Lingkungan kerja yang menyenangkan bagi pegawai melalui peningkatan hubungan yang harmonis dengan atasan, rekan kerja, maupun bawahan, serta didukung oleh sarana dan prasarana yang memadai yang ada di tempat kerja akan membawa dampak yang positif bagi pegawai, sehingga kinerja pegawai dapat meningkat. Temuan ini mendukung hasil kajian Surijadi \& Musa, (2020) yang menyatakan bahwa lingkungan kerja berpengaruh positif dan signifikan terhadap kinerja.

\section{Dampak Etos Kerja Terhadap Kinerja Pegawai}

Berdasarkan hasil analisis data, hipotesis penelitian yang menyatakan bahwa etos kerja berpengaruh terhadap kinerja pegawai di Dinas Pendidikan dan Kebudayaan Daerah Kabupaten Kepulauan Sangihe diterima. Pengaruh ini berdasarkan nilai t hitung $=9,03$ sedangkan $\mathrm{t}$ tabel $=2,00$. Hasil analisis data ini menjelaskan bahwa etos kerja memberikan kontribusi yang berarti terhadap kinerja pegawai.

Setiap pegawai atau pemimpin di suatu lembaga harus memiliki etos kerja yang tinggi, kalau tidak organisasi akan sulit berkembang, dan memenangkan persaingan dalam merebut pangsa pasarnya. Tasmara, (2002) menjabarkan etos kerja yang seharusnya dimiliki oleh seorang pegawai adalah totalitas kepribadian dirinya serta caranya mengekspresikan, memandang, meyakini dan memberikan makna ada sesuatu, yang mendorong dirinya untuk bertindak dan meraih amal yang optimal sehingga pola hubungan antara manusia dengan dirinya dan antara manusia dengan makhluk lainnya dapat terjalin dengan baik.

\section{Dampak Lingkungan Kerja dan Etos Kerja Terhadap Kinerja Pegawai}

Berdasarkan hasil analisis data, hipotesis penelitian yang menyatakan bahwa Ada pengaruh yang positif dan signifikan lingkungan kerja dan etos kerja terhadap kinerja 
pegawai diterima. Lingkungan kerja dan etos kerja sama-sama memiliki pengaruh yang positif terhadap kinerja pegawai. Lingkungan kerja yang kurang nyaman dan tidak kondusif serta etos kerja yang rendah menyebabkan target yang telah ditetapkan oleh kantor tidak dapat tercapai sebagaimana yang diharapkan. Hal ini dikarenakan pegawai cenderung malas bekerja di lingkungan yang kurang nyaman serta etos kerja yang rendah sehingga beberapa target yang telah ditetapkan tidak tercapai. Pegawai akan lebih giat dalam bekerja di lingkungan kerja yang kondusif serta di dorong oleh etos kerja yang tinggi dapat meningkatkan kinerjanya.

Hal ini menunjukan bahwa lingkungan kerja dan etos kerja memiliki pengaruh terhadap menurunnya kinerja pegawai di Dinas Pendidikan dan Kebudayaan Daerah Kabupaten Kepulauan Sangihe. Lingkungan kerja yang baik dan nyaman sangat berpengaruh terhadap kinerja pegawai, terbukti dari hasil penelitian yang menunjukkan adanya pengaruh yang positif dan signifikan antara lingkungan kerja terhadap kinerja pegawai. Selain itu etos kerja yang tinggi juga berpengaruh terhadap kinerja pegawai, terbukti dari hasil penelitian yang menunjukkan adanya pengaruh positif dan signifikan antara etos kerja terhadap kinerja pegawai. Dengan demikian, apabila kantor ingin mendapatkan hasil kerja yang maksimal maka perlu menciptakan lingkungan kerja yang nyaman dan kondusif serta etos kerja yang tinggi. Hal ini akan berdampak pada pencapaian target-target dan tujuan yang telah ditetapkan oleh instansi tersebut.

\section{Penutup}

Berdasarkan pembahasan hasil penelitian di atas maka yang menjadi kesimpulan dalam kajian ini adalah;

1. Terdapat pengaruh lingkungan kerja terhadap kinerja pegawai di Dinas Pendidikan dan Kebudayaan Daerah Kabupaten Kepulauan Sangihe.

2. Terdapat pengaruh etos kerja terhadap kinerja pegawai di Dinas Pendidikan dan Kebudayaan Daerah Kabupaten Kepulauan Sangihe.

3. Terdapat pengaruh secara bersama-sama lingkungan kerja dan etos kerja terhadap kinerja pegawai di Dinas Pendidikan dan Kebudayaan Daerah Kabupaten Kepulauan Sangihe. 


\section{Daftar Pustaka}

A.A Anwar Prabu Mangkunegara. (2005). Manajemen Sumber daya Manusia Perusahaan. Bandung: PT. Remadja Rosda Karya.

Alex Nitisemito. (2011). Manajemen Personalia (Manajemen Sumber Daya Manusia). Kudus: Ghalia Indonesia.

Arep, Ishak dan Hendri, T. (2003). Manajemen Sumber Daya Manusia. Jakarta: Universitas Trisakti.

Mangkunegara, A. A. . A. P. (2000). Manajemen Sumberdaya Manusia Perusahaan. Bandung: PT. Remaja Roksa Karya.

Salamun. (1995). Persepsi Etos Kerja Kaitannya Dengan Nilai Budaya Masyarakat Daerah Istimewa Yogyakarta. Yogyakarta: Yogyakarta Eka Putra.

Saleha. (2016). Pengaruh Lingkungan Kerja, Etos Kerja dan Budaya Kerja terhadap Kinerja Pegawai pada Dinas Bina Marga Propinsi Sulawesi Tengah. Jurnal Katalogis, 2(3), 196203.

Sinamo Jansen. (2011). Etos Kerja Profesional. Jakarta: Institut Dharma Mahardika.

Sondang P. Siagian. (2010). Manajemen Sumber Daya Manusia. Jakarta: Bumi Aksara.

Surijadi, H., \& Musa, M. N. D. (2020). Dampak Beban Kerja dan Lingkungan Kerja Terhadap Kinerja Pegawai. PUBLIC POLICY (Jurnal Aplikasi Kebijakan Publik \& Bisnis), 1(2), 114.

Tasmara, T. (2002). Membudayakan Etos Kerja Islami. Jakarta: Gema Insani Press.

Timpe, A. D. (1992). Kinerja (Seri Manajemen Sumber Daya Manusia). Jakarta: PT. Elex Media Komputindo.

Winardi. (2007). Manajemen Kinerja. Jakarta: PT. Raja Grafindo Persada.

Wirawan. (2009). Evaluasi Kinerja Sumber Daya Manusia Teori Aplikasi dan Penelitian. Jakarta: Salemba Empat. 